Article

\title{
Economic Valuation of Cultural Heritage Using the Travel Cost Method: The Historical Centre of the Municipality of Bucharest as a Case Study
}

\author{
Florentina-Cristina Merciu ${ }^{1}$ (D), Alexandru-Ionuţ Petrişor ${ }^{2,3, *(D)}$ and George-Laurenţiu Merciu ${ }^{1}$ \\ 1 Faculty of Geography, Interdisciplinary Center of Advanced Research on Territorial Dynamics, \\ University of Bucharest, 010041 Bucharest, Romania; cristina.merciu@geo.unibuc.ro (F.-C.M.); \\ george.merciu@geo.unibuc.ro (G.-L.M.) \\ 2 Doctoral School of Urban Planning, Ion Mincu University of Architecture and Urbanism, \\ 010014 Bucharest, Romania \\ 3 National Institute for Research and Development in Tourism, 50741 Bucharest, Romania \\ * Correspondence: alexandru_petrisor@yahoo.com; Tel.: +40-213-077-191
}

Citation: Merciu, F.-C.; Petrişor, A.-I. Merciu, G.-L. Economic Valuation of Cultural Heritage Using the Travel Cost Method: The Historical Centre of the Municipality of Bucharest as a Case Study. Heritage 2021, 4, 2356-2376. https://doi.org/10.3390/ heritage 4030133

Academic Editor: Dmitry A. Ruban

Received: 15 July 2021

Accepted: 10 September 2021

Published: 12 September 2021

Publisher's Note: MDPI stays neutral with regard to jurisdictional claims in published maps and institutional affiliations.

Copyright: () 2021 by the authors. Licensee MDPI, Basel, Switzerland. This article is an open access article distributed under the terms and conditions of the Creative Commons Attribution (CC BY) license (https:// creativecommons.org/licenses/by/ $4.0 /)$.

\begin{abstract}
Because heritage buildings represent a special category of goods due to characteristics such as uniqueness and irreversibility, they are associated with multiple possibilities of use. This article aims to present a complex analysis of the values associated with using heritage buildings in the historical center of Bucharest and their correlation with corresponding conservation measures using the travel cost method. The authors used two computation methods: the zonal travel cost and the individual travel cost methods. The application of Bravais-Pearson's coefficient of linear correlation confirmed that the demand for a cultural heritage site is inversely related to the travel costs and distance. The results reflect that the demand also depends on other factors, such as the satisfaction level of the tourist experience and tourists' income and motivations. The study highlights the usefulness of the travel cost method, which facilitates analyzing the relationship between the significant value of using historical monuments and the extremely important conservation process in the current context, marked by socioeconomic dynamics that determine many reuses of cultural heritage.
\end{abstract}

Keywords: nonmarket evaluation; willingness to pay; revealed preference method; contingent behavior; recreation

\section{Introduction}

The importance of the built heritage is associated, on the one hand, with a varied typology, but, on the other, with the multiple values that it incorporates (historical, architectural, artistic, aesthetic, social, authenticity, symbolic, cultural, and scientific) [1-13]. These values justify the need for cultural heritage to be preserved properly and reused [12-17] to ensure a sustainable development that means cultural heritage can be passed on to future generations [12]. At the same time, heritage buildings have an economic value [3-6,9,11-22] due to the fact that they have multiple possibilities for adaptive reuse [3,6,12]: for hosting various economic activities (hotels, restaurants, offices, shops, etc.) $[1,6,23,24]$. Some historic buildings that no longer retain their original function are also reused for cultural purposes [12,14-16,22] due to their particular characteristics (antiquity, architecture, symbolic value). Cultural reuses also ensure the tourist use of heritage buildings and are often considered an appropriate form of their conservation [14-16,22]. There are various forms of cultural reuse of heritage buildings, such as museums. Examples include the Alexandria National Museum, formerly a gathering place for the upper class of Egyptian society [14], D'Orsay train station in Paris, transformed into an art museum [25], Certosa di Pisa in Calci (Tuscany), a former Carthusian Monastery currently reused as a publicly owned museum center [15], Limassol castle, Larnaca Castle [22], and the former Royal Palace in Bucharest transformed into the National Museum of Art of Romania. In the recent years, museums 
have been transformed in heritage buildings located in cities that have won the title of European Capital of Culture. Other cultural reuses of heritage buildings are as centers of art and culture, exhibition centers (e.g., Othello Castle (Famagusta City, Cyprus), Paphos Castle [22]), etc.

Adaptive reuses of heritage buildings require an assessment of the compatibility of the new function from the perspective of sustainable principles, which also applies to cultural conversions, e.g., preserving architectural integrity [14,16,22], involving minimal changes, compatibility with the requirements of the new use [14,16], and even developing innovative standards and technologies for restoration and repair [13,22], or the energy efficiency criterion $[4,14]$. Adaptive reuse should preserve the symbolic values of historical buildings $[14,16,24]$.

Over time, the conservation process has become more and more complex, with the role of preserving the cultural heritage being integrated into a sustainable strategy $[15,26]$, involving the environmental, economic, and social dimensions, i.e., material and resource efficiency, cost reduction, and preservation of intrinsic values $[3,16]$. Thus, adaptive reuse allows both conservation of heritage buildings and their promotion as resources [15].

The economic value of heritage buildings overlaps with sociocultural values [3,6,12], and sometimes there is a conflict between the two $[3,6,16,26,27]$. In this context, the cultural heritage conservation and valorization refer to multiples values that it incorporates, also including economic constraints, technical aspects [3], and a large number of stakeholders with different levels of influence in the decision-making process $[3,6,16,28,29]$.

The reuse of heritage buildings is a priority action in the regeneration process, due to the fact that historical monuments are in different states of conservation, and some are unused [6,14,22-24]. Adaptive reuse is often seen as an alternative to demolition of heritage buildings [13,30], and relies on the principle of their continuous use [13,14,22]. Adaptive reuses of heritage buildings also involve consulting local communities [14,23], all these requiring to be correlated with the needs of local populations $[3,6,8,23,27]$.

Heritage properties are a particular category of goods that are not bought and sold on ordinary markets $[19,31]$, the economic valuation of which is performed indirectly by estimating the value of use that falls within the nonmarket valuation using revealed preference methods $[9,11,20,21,32-34]$. Assessing the use value is not easy because historical buildings have characteristics such as uniqueness and irreversibility [21], as well as a wide range of values that are impossible to measure in monetary terms (e.g., social value) [11,20].

In this study, the travel cost method is used to evaluate, for the first time, the use value of heritage buildings in the historical center of Bucharest. Thus, the observed behaviors of national tourists are analyzed (the actual number of trips to the analyzed historical site), as well as their declared behaviors (the number of trips that would be made in the study area in hypothetical circumstances). At the same time, through this method, the value of preserving cultural objectives is inferred based on the tourists' perception of the degree of conservation of heritage buildings in the studied historical site. This first evaluation of the ways of using heritage buildings in the historical center of Bucharest can be a useful tool for public administration representatives and planners when making decisions on the management of heritage assets at historical sites.

This study is significant because it aims to improve the application of the travel cost method by overcoming the problems identified from the analysis of the literature by considering many factors that can influence the decision to visit a cultural destination. Thus, the use value of historical buildings in the study area was evaluated, taking into account recommendations from the literature regarding the estimation of travel costs.

The study is divided into six sections. Section 1 presents the multiple valences associated with cultural heritage, which explain the multitude of adaptive reuses and complexity of its economic evaluation. Section 2 provides the theoretical context of the approach used by the transport cost method; the authors present the evolution of the method by referring to its limitations and importance. Section 3 presents how the transportation cost method was applied to the selected case study. Section 4 presents the study results. Section 5 
discusses the significance and importance of results, their limitations, and future directions of research. Section 6 summarizes the study conclusions, mentioning the importance of the method used for the economic evaluation and ranking of heritage buildings, taking into account the preferences of tourists.

\section{Background Literature}

The multitude of valences associated with cultural heritage justifies, on the one hand, its tourist attractiveness, and, on the other hand, the complexity of analyzing its usage values $[5,6,9,12,17,18,21,24,27]$ correlated with understanding the artistic significance of arts and culture and the value of cultural experience [35]. The economic evaluation of cultural heritage is performed using nonmarket valuation techniques that can be classified into two categories: revealed preference methods based on observed behaviors (transport cost method, hedonic price method) and stated preference methods (contingent valuation method). While stated preference methods are based on hypothetical scenarios to evaluate nonuse value, the revealed preference methods assess the value of use of cultural heritage through real behavior (e.g., cost of travel, frequency of visits, etc.) $[5,6,9,12,18,21,24,27,35,36]$.

Initially, both categories of methods were applied in environmental economics [33,35]. In recent years, these methods have been frequently used for the economic evaluation of cultural heritage $[6,9,12,18-21,24,27,35]$.

The travel cost method is a model for travel forecasting and is a key component of the estimation of the number of journeys that tourists will make to a particular historical site or monument [18,20,31,33,35-38].

The travel cost method is based on the demand theory, which assumes that the demand for a recreational destination (a natural or cultural one) is inversely related to the travel costs that a visitor is willing to pay as a result of assessing its characteristics [19,20,32-35]. Moreover, travel cost analysis is carried out to assess the benefits generated by cultural heritage elements: a price per visit that "reveals" visitors' willingness to pay (accommodation, entrance fees, and transport) to enjoy cultural goods $[19,20,33,34]$. Thus, the analysis of travel costs is included in the category of methods based on revealed preferences because it uses tourists' behavior and effective choices to deduce the use values of tourist sites [36] (p. 1385).

The analysis of previous studies facilitated the exploration of the evolution of this method's application. Thus, a series of limitations in its application related to the identification and inclusion of several factors that influence the cost of a trip made for tourism purposes was revealed. For example, the time allocated by a person to a recreational trip may be limited by that person's type of job (part- or full-time) $[20,21,36]$. Hence, some authors propose the inclusion of the time cost in the evaluation of the total travel cost $[20,36,39,40]$.

The difficulty of assessing travel costs arises in situations in which a trip is focused on visiting several tourist destinations $[11,20,21]$, due to the fact that the estimated cost of the trip must be computed for each destination as well as the demand for each destination [36]. However, some authors [20] consider this solution to be incomplete because the total cost is greatly reduced when divided between several destinations.

The multisite model uses random utility maximization, which assumes that people's choice is determined by the experience offered by the historical site. It is assumed that, in choosing a site, visitors take into account the cost of their trip and the characteristics of the heritage site (e.g., historical and architectural value, the value of authenticity, etc.) [11] (p. 337). There are a number of controversies about the types of costs that should be considered to obtain the most accurate estimate of the cost of travel. It must include the costs related to fuel consumption, entrance fees to cultural sites, and parking fees [20,21,36,38,39]. Regarding the cost of fuel, some studies specify that the expenses related to the maintenance of the personal car, insurance, and costs related to the changing of tires must also be taken into account $[20,21,41]$. Other studies mention that the total cost of travel must include 
the costs of accommodation and meals $[20,21,38,39,41]$ because they contribute to the recreational experience [21].

Another difficulty in estimating travel costs is the possibility for tourists to opt out of alternative tourist destinations [11,20,21,36,39]. This situation is less probable in the case of cultural destinations because they have unique tourist resources, which justify the repetition of visits [20,36]; however, some authors do not exclude the possibility of tourists choosing an alternative destination in some situations, regardless of whether it is cultural, taking into account the possibility of substituting goods, especially if the destinations have similar characteristics [20]. There are two possibilities in this situation: to include all the prices of substituted sites, which would generate the risk of a high correlation between the price variables and result in an unstable estimation of the price elasticity, or to omit the prices of substituted sites, generating prejudices, but nevertheless a stable estimate of the price elasticity that would result [20] (p. 104).

The quality of tourist destinations, especially cultural ones, and congestion are important factors that can influence the cost of travel. In the case of cultural destinations, two types can be identified: well-preserved and well-managed historical sites; aspects that can generate a high degree of visitor appreciation, and sites that have been neglected and are in a state of degradation $[19,20]$. Thus, the quality of the site is a determining factor in tourists choice of destinations $[20,21,36,37]$. On the other hand, congestion is a problem that affects the quality of a cultural destination [20,36]. Using price as a means of limiting the tourist traffic to historic sites is considered as an inefficient measure, as sites tend to have entrance fees that are very low or zero. The demand is shown to be underestimated in the event of congestion, and the travel cost method provides an estimate of the consumer's surplus below the real value [20] (pp. 104-105). However, if we take into account the cultural sites that are highly appreciated due to their exceptional values, particularly those inscribed in UNESCO's heritage, the volume of visits will be high even if they are conditioned by the payment of entrance fees.

It is considered as a general criticism that ignoring the admission effect results in the same marginal monetary utility for all visitors, although the marginal cost of the visit depends on their income level [20] (p. 105). Thus, some authors [20] propose to ignore this restriction because the consumption of cultural resources can represent only a part of a person's budget, and the effects of price changes influence the real income of agents to a small extent.

Another criticism of the travel cost method in relation to assessing the values of use of cultural goods is that the method is based on a strictly economic, financial approach and does not take into account other aspects specific to heritage properties, for example their artistic and cultural value or a set of political criteria for the maintenance of cultural heritage [16]. Thus, this method contributes to the knowledge of tourists' preferences, regardless of the cultural significance of the studied sites [20] (p. 110). However, some authors [16] consider that visitors' desire to pay to visit cultural sites simultaneously reveals the cultural value that they attribute to them, while the influx of visitors and their spending indicate the importance of the tourist location [36].

In relation to this idea, a criticism of this method of evaluation is that it should be able to measure the values of several attributes of the historical property. The travel cost method involves the evaluation of the patrimonial good as a whole, without decomposing it into a set of attributes [11] (p. 343). Moreover, the idea according to which the human personality is formed and rooted in the aspect of historical values and the human acceptance of values is performed creatively, and actively can be highlighted in relation to the selection of elements of cultural heritage to visit [36]. Thus, taking into account the opinions of specialists, it can be appreciated that value guides individuals in making decisions in different social situations, implicitly causing them to select activities that meet their psychological needs [36].

Referring to visits to cultural sites that satisfy both the need for recreation and the need for knowledge, we note the usefulness of the travel cost method due to the fact that it allows 
us to identify the factors that were at the root of the decision to visit them. An advantage of this method is that it uses information about real behavior rather than visitors' responses to hypothetical scenarios related with the application of stated preference methods [35,36,42]. The use of the transport cost method in the evaluation of cultural experience produces considerably higher estimates compared to the contingent evaluation method, especially if it is applied for a single cultural site [35].

\section{Materials and Methods}

\subsection{Case Study}

The capital city of Romania is distinguished by a varied typology of cultural heritage elements as a result of its long evolution (starting with the Voivodship Residence of Prince Vlad Ţepeş, built between 1458 and 1459, which in turn contained the brick foundations of a rectangular fortress from the 14th century in its basement [43] (p. 125). The construction of the Voivodship Court favored the development of commercial activity, which has lasted until now. The historical center of Bucharest is individualized in the urban landscape by a medieval-type urban fabric (narrow streets) and by the presence of buildings with architectural value (specific to the 18th-19th centuries) $[6,10]$ (Figure 1).

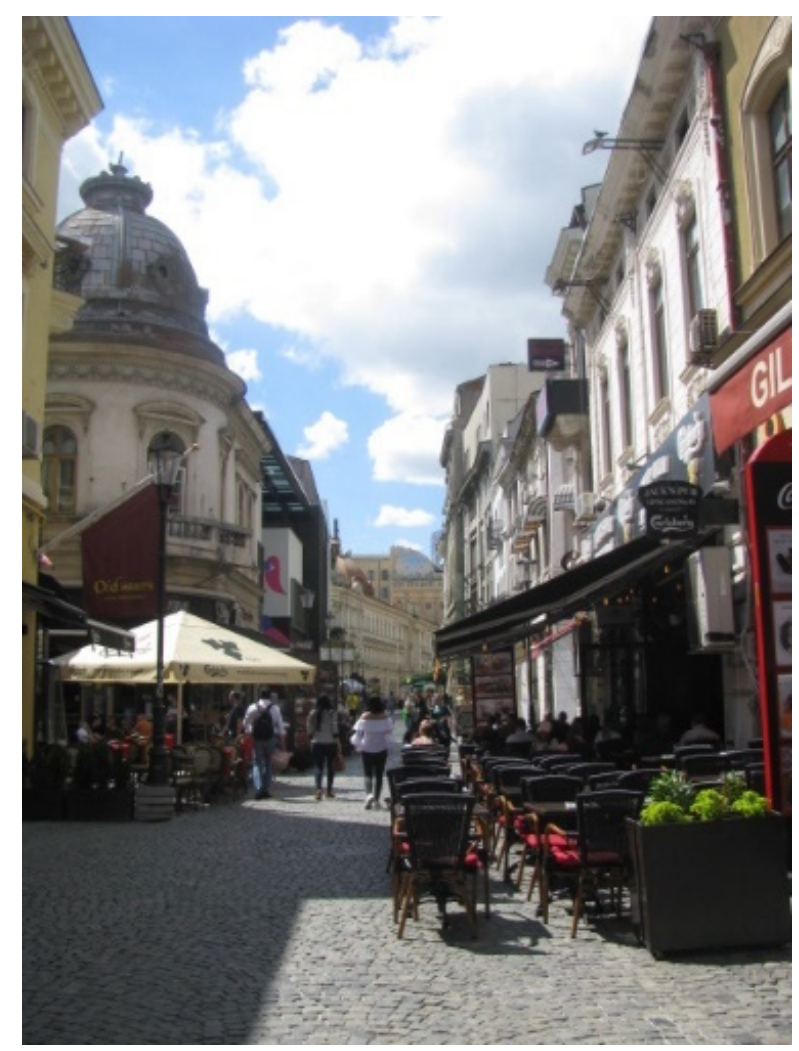

Figure 1. Medieval urban texture-the historical center of Bucharest. Source: Merciu, F.-C. (June 2019).

The historical center hosts many cultural sites that are representative of the capital city [10], which are individualized by uniqueness and historical and architectural value. The medieval ruins of the Voivodeship Court have been entirely excavated, preserved, and restored, and subsequently capitalized in the form of a museum project since 1970 [43] (p. 125). Other important cultural sites are the National History Museum, where a small part of Romania's treasury is located, numerous civic and religious buildings (most built in the 19th century in the neoclassical and neo-Baroque styles), and buildings that still host commercial activities and public catering that are very well known: Manuc's Inn, Lime Inn, 
the Beer Cart (a building with architectural and historical value, a restaurant famous for Romanian gastronomy), and so on.

\subsection{Methods}

The authors used two computations of this model: the zonal travel cost method and the individual travel cost method.

The zonal travel cost method was applied, taking into account tourists' areas of origin, which were delimited based on the distance travelled from their point of origin to the cultural destination [20]. This method was initially developed by the authors [44], highlighting, as the main factor, that the distance influences the volume of tourist demand because it is an important factor of expenses.

Recent studies suggest the possibility of representing the areas of origin of tourists using geographical or even administrative boundaries [34]. The administrative borders of the counties were used in representation, and the borders of development regions marked. Circles corresponding to the number of tourists were superimposed over the outline of counties. Five differences were established to represent the variation of the number of tourists who opted to visit the historic center of Bucharest.

Studies conducted on this topic over time highlight a number of limitations of the zonal travel cost method, for example, emphasizing that other factors besides distance can influence tourists' choice to visit a cultural site (budget and time constraints and the site's quality $[19-21,36,37]$ or sociocultural factors $[18,19,33,34])$.

In recent years, in addition to distance, other elements, such as accessibility, have been integrated into the computation of the zonal transport cost method due to the fact that other factors can also influence the volume of demand (e.g., travel-impeding factors: the legal speed limit, terrain morphology, road network density, etc.) [45]. Thus, accessibility is computed using the kernel method, which supposes the processing of data stored in a GIS (geodatabase) environment. Different degrees of accessibility are computed depending on the efficient and consistent management of relationships between datasets: the distribution of the road network $[45,46]$ and different types of roads and their length (highway segments, European roads, and national, communal, and local roads) [45]. With the establishment of different sections of roads, the maximum legal speed is assigned to them (e.g., for roads of national importance, the average speed is $90 \mathrm{~km}$ an hour, for secondary roads it is $70 \mathrm{~km}$, and for highways it is $130 \mathrm{~km}$ ).

Subsequently, the method of individual travel costs was developed. This method is used to estimate the demand for leisure goods for each individual at a particular tourist destination. In this case, the dependent variable is the number of visits made by each person, which means that the cost of a trip can vary from one person to another even if their point of origin is the same [20] (p. 103). This method also pinpoints other factors that may influence the frequency of visits, adding a number of budget and time constraints to the distance [20,36]. These are related to a person's employment conditions [20] (p. 103). In other words, to enjoy recreational activities in a tourist destination, tourists must sacrifice the opportunity to earn money [36]. The method of individual travel costs aims to eliminate the limitations of the zonal model and uses data about visitors rather than about the recreational area [39].

A structured questionnaire was applied to identify the factors that influence the tourists' willingness to visit the historical center of Bucharest. It was also necessary to compute the travel cost, making a distinction between tourists who travelled by car and those who travelled by plane or train. The computation of the travel cost was also conducted according to the price of fuel for a round trip, the duration of the trip, vehicle maintenance and depreciation, insurance, entrance fees, and travel time [20,34]. In the case of air travel, the cost was computed on the basis of the fees charged by airlines. Some studies consider that the cost of travel should include the salary of a person during a tourist visit [20], on the assumption that visitors have paid leave and thus invest in the days of their trip. 
The individual transport cost method was applied to collect a larger amount of data in order to improve the quality of the studied cultural site, which positively influenced the cultural experience of tourists. First of all, tourists received questions about their current visit (quality of cultural recreation services, state of conservation of heritage buildings, level of satisfaction, etc.). In the second part of questionnaire, a hypothetical program is proposed to improve the quality of historical site and/or of the tourists' experience. The program was divided into three initiatives that would contribute to conserving cultural resources, improving the quality of services and infrastructure and limiting the negative effects on cultural heritage. Tourists were asked to propose these initiatives to improve the quality of historic site visited and services used.

The individual travel cost method also involves the statistical processing of data obtained from the application of structured questionnaires. This method estimates the demand for cultural goods for each individual in the study area. In this case, the dependent variables were the number of visits made to the site and the cost of transport, which means that the cost of travel may vary from person to person even if the point of origin is the same.

Data

The structure of the questionnaire focused on the travel cost method following different references $[18-20,37,38]$. The questionnaire was applied to 206 visitors during the tourist season, between 1 June and 15 August 2019. The questionnaires were applied by the authors at different points within the study area (Stavropoleos church, near the Voivodeship Court, or other buildings such as the Arcub Cultural Center, where different cultural activities were frequently organized before the COVID-19 pandemic). Since the questionnaire included 20 questions, the authors preferred to apply the tourists' questionnaires directly to ensure that all questions would be answered.

The sample was intended to capture the characteristics of tourists who show a special interest in cultural tourism as well as those who have the desire to visit cultural objectives as a secondary motivation. From this perspective, it was aimed, from the respondents' age point of view, to select visitors aged between 18-50 years with an average or higher education level. The authors also considered important the inclusion of visitors who have the visit of cultural objectives as a secondary option, because this motivation is a factor that stimulates the trips and the possibility to repeat them.

In the first part of the questionnaire, data about the visit were collected (e.g., the respondents were asked to specify how many visits they had made to the central area of the city in the last 12 months, the mode of travel, the motivations for their visit, the use of catering and accommodation, and the length of stay). To obtain the key inputs for the travel cost model, the respondents were asked to state how far they live from the area visited and indicate the type of expenses incurred. At the same time, they were asked to rate their level of satisfaction with the tourist experience and perception of the state of conservation of cultural heritage, reporting on a scale from 1 to 5 , where 1 represents the worst experience and 5 the best.

The second part of the questionnaire focused on interviewing respondents on the proposed measures to improve the quality of the tourist experience, focusing on three categories: respondents' proposals for heritage buildings (conservation), and improving infrastructure and services. The respondents were asked how often they would visit the cultural destination if the cost did not change in the next period and whether they would visit again if the cost of the visit increased by $20 \%$.

In the last part of the questionnaire, information on sociodemographic characteristics was gathered. The sociodemographic profile of the respondents reflects a balanced gender distribution (51\% women and $49 \%$ men). Prior to conducting the analyses, data were recorded to simplify the responses and interpret them more easily. As far as possible, we attempted to transform each qualitative variable at least into a rank/scale variable. The recoding is presented in Table 1 . 
The statistical analyses consisted of two methods, the analysis of covariance (ANCOVA/ANACOVA) and correlation analysis. The first approach considers the influence of a set of predictors (numerical, ranked, or qualitative data) on explaining the variability of a response variable. In this case, the response variables were the number of visits and the cost of travel. For each of the two variables, two models were developed; the first model was a full model, developed for analytical purposes, that is, for ascertaining the influence of the model and each predictor (given the presence of the others in the model) on the response variable. The full model included the variables with sufficient data, that is, the length of stay, tourist motivation, level of satisfaction with the tourist experience, income, willingness to return to the cultural destination if the cost of the stay increased by $20 \%$, gender, age, and, for each response variable, the other response variable. The full model was refined by "backward selection" into a prediction model, which included only the predictors with a significant influence on the response variables. Provided that the dataset was not too large, the prediction models were developed for two significance levels ( $p \leq 0.1$ and, respectively, $p \leq 0.05$ ). The correlation analysis consisted of computing Bravais-Pearson's coefficient of linear correlation and its statistical significance for all possible pairs of numerical and rank variables included in the model.

Table 1. Recoding of the variables.

\begin{tabular}{|c|c|c|}
\hline Variable & Answer or Class & Recoded Answer \\
\hline \multirow{5}{*}{ Satisfaction level } & Worst experience & 1 \\
\hline & Bad experience & 2 \\
\hline & Satisfactory experience & 3 \\
\hline & Good experience & 4 \\
\hline & The best experience & 5 \\
\hline \multirow{4}{*}{ Tourist motivations } & Cultural tourism & 1 \\
\hline & Business tourism & 2 \\
\hline & Conference participation & 3 \\
\hline & Visiting relatives, friends & 4 \\
\hline \multirow{3}{*}{ Income (RON) } & Under 1500 & 1 \\
\hline & $1501-3000$ & 2 \\
\hline & $3001-5000$ & 3 \\
\hline \multirow{4}{*}{ Culture: proposals for improvements } & Over 5000 & 4 \\
\hline & Consolidation of buildings with seismic risk; restoration & 1 \\
\hline & Reuse of abandoned buildings; cultural reuses & 2 \\
\hline & He/she does not know & 3 \\
\hline \multirow{5}{*}{$\begin{array}{l}\text { Infrastructure: proposals for } \\
\text { improvements } \\
\text { Services: proposals for improvements }\end{array}$} & Expansion and improvement of cultural infrastructure & 1 \\
\hline & General infrastructure improvement & 2 \\
\hline & Creative industries development & 3 \\
\hline & $\mathrm{He} /$ she does not know & 4 \\
\hline & Improving tourist services, including promotional activities & 1 \\
\hline \multirow{2}{*}{ Studies } & $\begin{array}{l}\text { Diversification of cultural services, including promotional } \\
\text { activities }\end{array}$ & 2 \\
\hline & Improving sanitation services & 3 \\
\hline
\end{tabular}

\section{Results}

In the first stage, the authors applied the zonal travel cost method, which classifies the data according to the visitors' areas of origin. These areas are differentiated as follows: the counties in the south and southeast of the country, located within the first and second lines that surround Bucharest (Ilfov, Giurgiu, Teleorman, Ialomița, Călărași, Prahova, and Dâmbovița), are the areas from which just over half (52\%) of the total number of tourists interviewed came (Figure 2). The other $48 \%$ of tourists travelled greater distances, from counties located in the south-central part of the country (Sibiu, Brașov, and Vâlcea), the southeast and east (Buzău, Brăila, Galați, and Iași), or the southwest (Dolj and Gorj) 
(Figure 2). Most tourists who chose to visit the country's capital (84\%) came from large and medium-sized urban centers.

The analysis of the degree of accessibility of the study area, computed by referring to the areas of origin of the tourists, indicates spatial differences due to the quality and distribution of the road network at the national level. Romania has a small share of highway segments. The presence of the Bucharest-Piteşti (A1), Bucharest-Constanţa (A2), and Bucharest-Ploieşti (A3) highways is noticeable since the accessibility along them is very high. Roads of high importance must be added due to the possibility of driving at higher speeds, for example, Bucharest-Giurgiu (an express road) and the European road E85 (Bucharest-Iaşi, in the eastern part of the country), reflecting higher values of accessibility along these routes. There are lower values in the areas with county roads, which have lower legal speed limits.

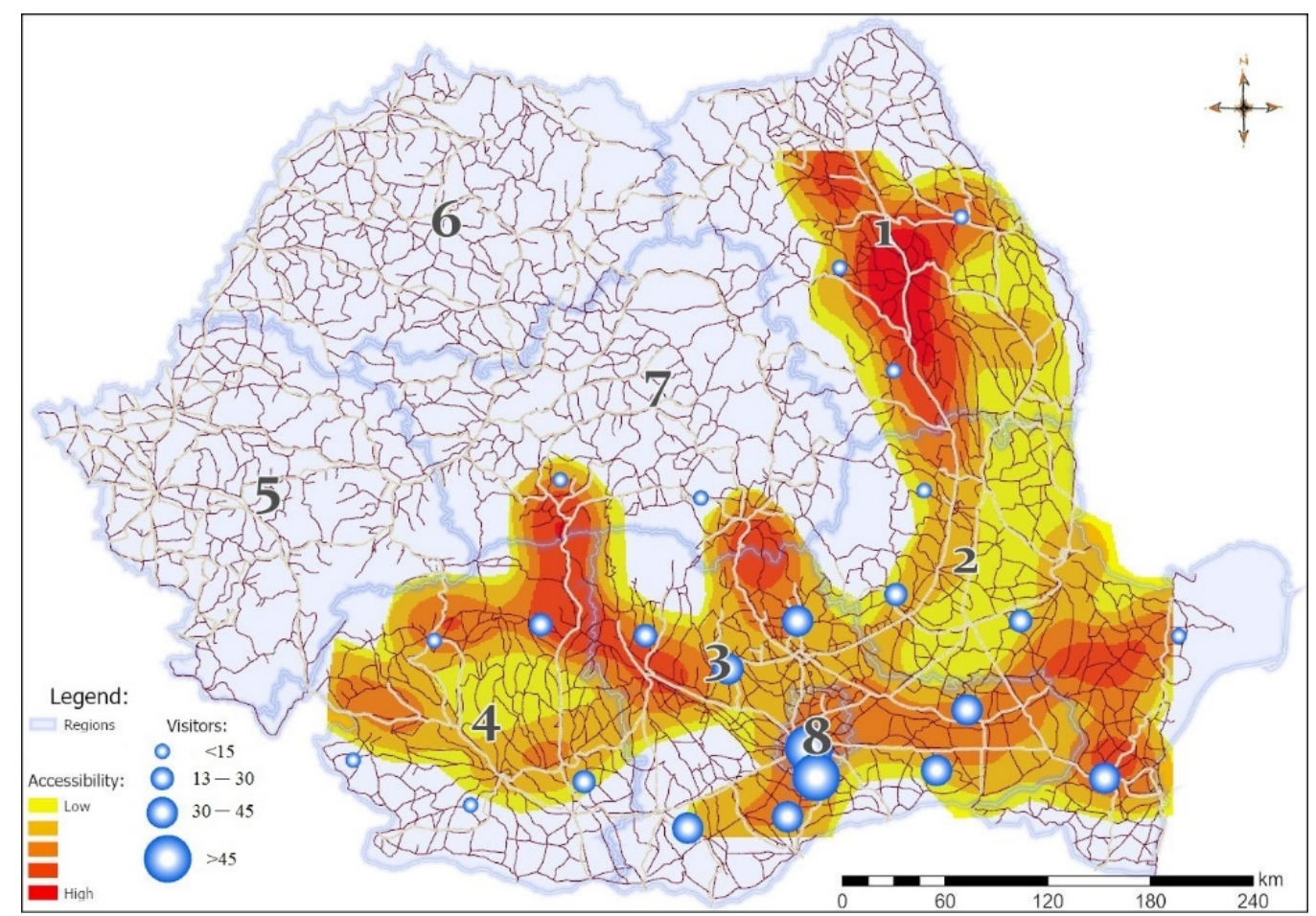

Figure 2. Tourist flows by area of origin and degree of accessibility of the study area using the zonal travel cost method. 1: Northeast region, 2: southeast region, 3: south-Muntenia region, 4: southwest region, 5: west region, 6: northwest region, 7: center region, 8: Bucharest-Ilfov region.

The data on the areas of origin of tourists and the number of tourists from each one were superimposed on the accessibility map of Bucharest, computed based on the areas of origin of tourists. The authors established differences in the number of tourists and degrees of accessibility. Thus, the data resulting from the application of the zonal transport cost method were correlated with those obtained for calculating accessibility using GIS. Due to the combined use of the two, as a result of the overlap of several data, the authors identified different correlations on the number of tourists and areas of origin. On the one hand, it is observed that the number of tourists decreases as the distances increase. On the other hand, the number of tourists could be also better explained by referring to the degree of accessibility from the capital city. A relatively large number of tourists come from areas located $220 \mathrm{~km}$ away from the capital city, due to better transport infrastructure that allows a shorter travel time (for example, settlements in the southeast of the country, due to the Bucharest-Constanta highway).

The authors also applied the method of individual travel costs, based on the analysis of the answers of respondents who had visited the historical center of Bucharest. The 
results of the ANCOVA/ANACOVA are presented in Table 2. All the models were overall significant at $p \leq 0.0001$ based on the results of the global $\mathrm{F}$ test, meaning that the predictors included in each model had, altogether, a significant role in explaining the variability of the number of visits and cost of travel.

The predictors with the highest values are the level of satisfaction with the tourist experience and tourist motivations, followed by respondents' perception of the conservation of the heritage buildings, duration of stay, and willingness to return even if the travel cost increases by $20 \%$.

The tourist motivations constitute an important predictor. The authors identified four types: cultural motivation (indicated by $67 \%$ of the total number of respondents), business tourism $(20 \%)$, participation in conferences $(9 \%)$, and visiting friends and relatives $(4 \%)$. The last three are also associated with cultural visits as secondary motivation (Figure 3).

Table 2. Results of the analysis of covariance assessing the influence of different predictors on the number visits and cost of transport. Bold italic font indicates the predictors with a significant influence at $p \leq 0.05$ and italic font indicates those that are significant at $p \leq 0.1$.

\begin{tabular}{|c|c|c|c|c|c|c|}
\hline \multirow{2}{*}{$\begin{array}{c}\text { Response } \\
\text { Variable }\end{array}$} & \multicolumn{3}{|c|}{ Number of Visits } & \multicolumn{3}{|c|}{ Cost of Transport } \\
\hline & Predictor & F Value & Significance $(p)$ & Predictor & F Value & Significance $(p)$ \\
\hline \multirow{9}{*}{ Full } & Cost of transport & 1.78 & 0.1836 & No. of visits & 1.78 & 0.1836 \\
\hline & Duration of the stay & 5.48 & 0.0202 & Duration of the stay & 0.54 & 0.4642 \\
\hline & Motivations & 28.02 & $<0.0001$ & Motivations & 0.29 & 0.8337 \\
\hline & Satisfaction level & 29.23 & $<0.0001$ & Satisfaction level & 17.08 & $<0.0001$ \\
\hline & Income & 5.23 & 0.0233 & Income & 3.12 & 0.0790 \\
\hline & $\begin{array}{l}\text { Willingness to return } \\
\text { if the cost of stay } \\
\text { increased by } 20 \%\end{array}$ & 6.23 & 0.0134 & $\begin{array}{l}\text { Willingness to return } \\
\text { if the cost of stay } \\
\text { increased by } 20 \%\end{array}$ & 15.80 & $<0.0001$ \\
\hline & $\begin{array}{l}\text { Perception of } \\
\text { conservation }\end{array}$ & 10.89 & 0.0012 & $\begin{array}{l}\text { Perception of } \\
\text { conservation }\end{array}$ & 0.48 & 0.4877 \\
\hline & Gender & 0.53 & 0.4686 & Gender & 0.04 & 0.8361 \\
\hline & Age & 1.93 & 0.1665 & Age & 4.68 & 0.0317 \\
\hline \multirow{4}{*}{$\begin{array}{c}\text { Prediction } \\
(p \leq 0.1)\end{array}$} & & & & Satisfaction level & 14.62 & 0.0002 \\
\hline & & & & Income & 3.47 & 0.0640 \\
\hline & & & & $\begin{array}{l}\text { Willingness to return } \\
\text { if the cost of stay } \\
\text { increased by } 20 \%\end{array}$ & 20.45 & $<0.0001$ \\
\hline & & & & Age & 5.09 & 0.0251 \\
\hline $\begin{array}{l}\text { Prediction } \\
(p \leq 0.05)\end{array}$ & & & & Age & 15.42 & 0.0001 \\
\hline
\end{tabular}

The last three motivations are important both in terms of weight, accounting for a third of the total number of respondents, and because they are also associated with the cultural motivation, which, as a result of the dynamics, generates multiple visits. On the other hand, motivations such as business meetings, participation in conferences, or visiting relatives and friends also stimulate tourist visits, implicitly those associated with cultural tourism, due to the fact that these categories of visitors divide their time between work and relaxation and visiting cultural sites.

The high value of the level of satisfaction with the tourist experience (17.08) predictor reflects the desire to repeat the visit even if the cost of the trip increases by $20 \%$ ( 20.45 value) (Table 2). All the respondents will return if the cost of travel remains the same, and 118 visitors (57\%) will return if the cost of travel increases by $20 \%$, reflecting a decrease in the number of visits as the transportation cost and distance increase. 
At the same time, it is noticeable that tourists who have visited the area two or three times, knowing the cultural destination better, have a perception of the problems faced by this area, particularly the presence of buildings that need renovation or consolidation. This fact is indicated by the relatively high value of the predictor "perception of conservation of heritage buildings" (10.89). At the same time, proposals regarding the conservation of heritage buildings in the historical center of Bucharest reflect tourists' preoccupation with the state of conservation of buildings with architectural value and a desire to enjoy them.

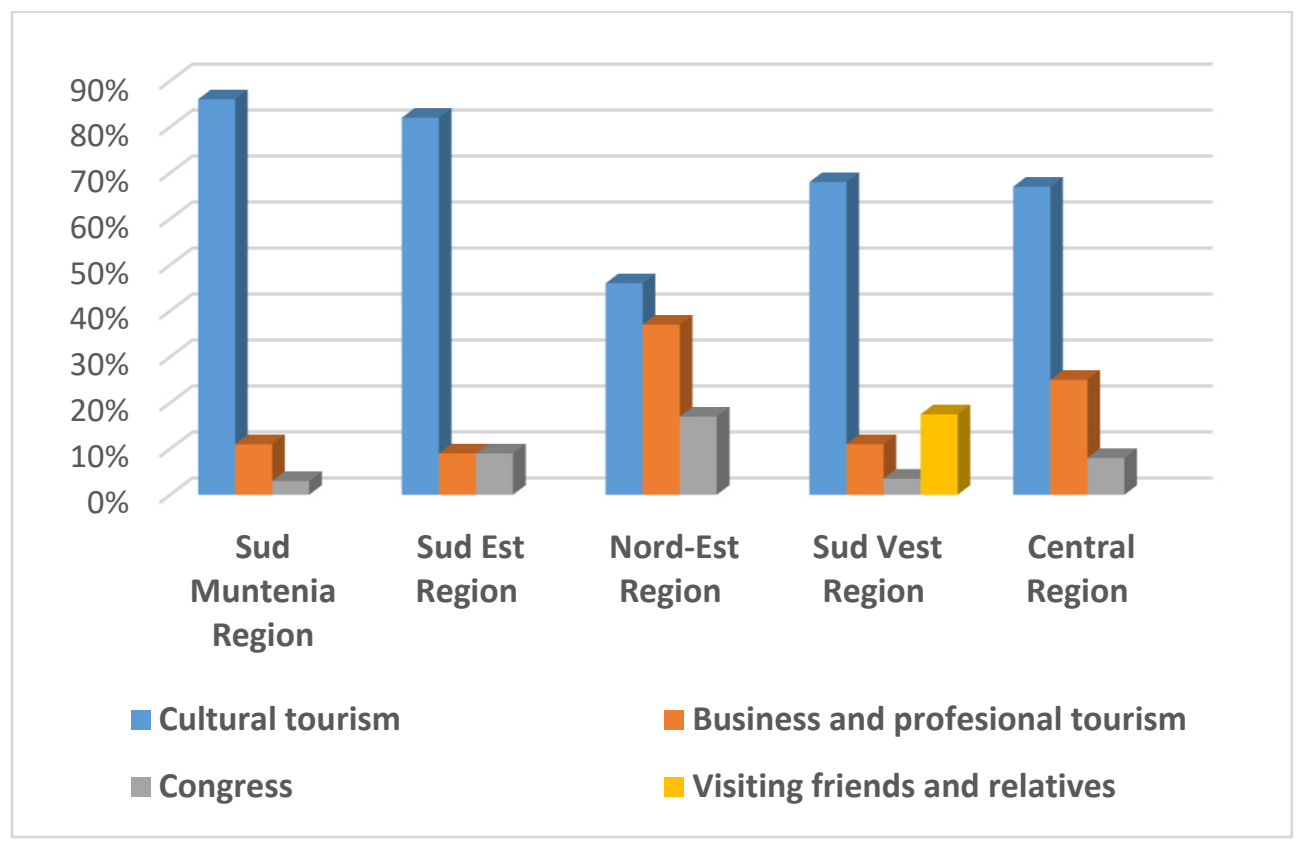

Figure 3. Distribution of forms of tourism practiced by respondents in the historical center of Bucharest.

The results of the correlation analysis are presented in Table 3. There is a correlation between the distance travelled from the area of origin to the cultural destination and the duration of the stay (0.542), noting a stay of at least 2 days for tourists from counties located at a distance of up to $120 \mathrm{~km}$ from the capital city. The tourists who come from counties located at greater distances from Bucharest (between 200 and $300 \mathrm{~km}$ ) opted for a 3-day stay.

There is a correlation between the cost of transport and the duration of stay (0.149), the number of visits (0.162), the level of satisfaction with the tourist experience $(0.346)$, and the income (0.315). Most tourists (75\%) opted for personal car transport, and a third of them have high incomes. This situation is also explained by the fact that most tourists who have high incomes $(90 \%)$ and who used their personal car as a means of transport have business meetings as their main motivation, the cultural motivation being secondary. In this situation, it is the business motivation that generates multiple visits. Even though the cultural motivation is secondary, it occupies about one-third of the tourists' stay during each visit. At the same time, among the tourists who have made repeated visits to the historical center, one-third have participation in meetings, such as conferences, as their main motivation, and the cultural motivation is secondary.

The distance also correlates with the number of visits (0.456), with almost half of the respondents (39\%) having visited the historical center of Bucharest twice, most of whom were from the south-Muntenia region (35\%), followed by the central region (23\%), southeast $(22 \%)$, southwest $(11.5 \%)$, and northeast $(8.5 \%)$. 
Table 3. Correlations of all the numerical or rank variables included in the study. Bold italic font indicates the predictors with a significant influence at $p \leq 0.05$ and italic font indicates those that are significant at $p \leq 0.1$.

\begin{tabular}{|c|c|c|c|c|c|c|c|c|c|}
\hline Model & Distance & $\begin{array}{c}\text { Cost of } \\
\text { Transport }\end{array}$ & $\begin{array}{c}\text { Duration } \\
\text { of Stay }\end{array}$ & $\begin{array}{l}\text { No. of } \\
\text { Visits }\end{array}$ & $\begin{array}{l}\text { Satisfaction } \\
\text { Level }\end{array}$ & Income & $\begin{array}{l}\text { Perception of } \\
\text { Conservation }\end{array}$ & Age & Studies \\
\hline \multirow{2}{*}{ Distance } & 1.000 & 0.106 & 0.542 & 0.456 & 0.324 & 0.241 & 0.009 & 0.137 & 0.191 \\
\hline & & 0.131 & $<0.0001$ & $<0.0001$ & $<0.0001$ & 0.001 & 0.894 & 0.049 & 0.006 \\
\hline \multirow{2}{*}{$\begin{array}{l}\text { Cost of } \\
\text { transport }\end{array}$} & 0.106 & 1.000 & 0.149 & 0.162 & 0.346 & 0.315 & 0.016 & 0.266 & 0.313 \\
\hline & 0.131 & & 0.033 & 0.020 & $<0.0001$ & $<0.0001$ & 0.821 & 0.000 & $<0.0001$ \\
\hline \multirow{2}{*}{$\begin{array}{l}\text { Duration of } \\
\text { stay }\end{array}$} & 0.542 & 0.149 & 1.000 & 0.374 & 0.351 & 0.289 & -0.040 & 0.172 & 0.227 \\
\hline & $<0.0001$ & 0.033 & & $<0.0001$ & $<0.0001$ & $<0.0001$ & 0.566 & 0.014 & 0.001 \\
\hline \multirow{2}{*}{ No. of visits } & 0.456 & 0.162 & 0.374 & 1.000 & 0.463 & 0.318 & 0.118 & 0.073 & 0.226 \\
\hline & $<0.0001$ & 0.020 & $<0.0001$ & & $<0.0001$ & $<0.0001$ & 0.093 & 0.300 & 0.001 \\
\hline \multirow{2}{*}{$\begin{array}{l}\text { Satisfaction } \\
\text { level }\end{array}$} & 0.324 & 0.346 & 0.351 & 0.463 & 1.000 & 0.349 & -0.060 & 0.090 & 0.263 \\
\hline & $<0.0001$ & $<0.0001$ & $<0.0001$ & $<0.0001$ & & $<0.0001$ & 0.396 & 0.197 & 0.000 \\
\hline \multirow{2}{*}{ Income } & 0.241 & 0.315 & 0.289 & 0.318 & 0.349 & 1.000 & -0.030 & 0.330 & 0.573 \\
\hline & 0.001 & $<0.0001$ & $<0.0001$ & $<0.0001$ & $<0.0001$ & & 0.674 & $<0.0001$ & $<0.0001$ \\
\hline \multirow{2}{*}{$\begin{array}{l}\text { Perception of } \\
\text { conservation }\end{array}$} & 0.009 & 0.016 & -0.040 & 0.118 & -0.060 & -0.030 & 1.000 & 0.011 & -0.077 \\
\hline & 0.894 & 0.821 & 0.566 & 0.093 & 0.396 & 0.674 & & 0.873 & 0.270 \\
\hline \multirow{2}{*}{ Age } & 0.137 & 0.266 & 0.172 & 0.073 & 0.090 & 0.330 & 0.011 & 1.000 & 0.296 \\
\hline & 0.049 & 0.000 & 0.014 & 0.300 & 0.197 & $<0.0001$ & 0.873 & & $<0.0001$ \\
\hline \multirow{2}{*}{ Studies } & 0.191 & 0.313 & 0.227 & 0.226 & 0.263 & 0.573 & -0.077 & 0.296 & 1.000 \\
\hline & 0.006 & $<0.0001$ & 0.001 & 0.001 & 0.000 & $<0.0001$ & 0.270 & $<0.0001$ & \\
\hline
\end{tabular}

The analysis of responses related to visitors' behavior reflects a positive correlation between the number of visits and the desire to return to the historical center. Almost half of the respondents ( $45 \%$ ) had visited the analyzed cultural destination twice (112 people), and seven had visited three times.

The analysis of the travel cost highlighted a series of differences: in the case of tourists who chose to use their personal car $(80 \%)$, the costs were higher, around RON 2800 (EUR 600), reaching values between RON 3300 and 3500 (EUR 670-700). The total price of fuel also included expenses related to car insurance. The total cost was differentiated by the distance between the area of residence and the cultural destination, by the amount of accommodation, and by the availability of meals served at a restaurant. An average travel cost of about RON 1200 (EUR 250) was computed for a person who chose to use the plane as a means of transport on the route Bucharest-Iasi for a stay with a duration of 3 nights.

The lowest travel costs were found for tourists who used the train (19\% of the respondents). More than half of the people who used the train as a means of transport came from places situated a shorter distance away (between 30 and $100 \mathrm{~km}$ from the capital city). Within this category of tourists, depending on their income, some respondents opted for cheaper forms of accommodation, a situation in which the total cost of transport varied between RON 200 and RON 300 (less than EUR 100) due to the fact that the stay was shorter. For other respondents, opting for more expensive forms of accommodation, the total cost of travel was higher (between RON 400 and RON 500, respectively, about EUR 100). A quarter of the respondents who used the train as a means of transport came from places situated at distances greater than $150 \mathrm{~km}$ and opted for accommodation, resulting in a total cost of RON 700-800 (respectively, EUR 150-170).

Regarding the respondents' proposals, it was observed that almost half of them $(49 \%)$ highlighted the problem of buildings being in a precarious state of preservation and requiring consolidation or restoration actions. Some respondents mentioned the cultural reuse of abandoned buildings as a post-consolidation action as a solution for conserving heritage buildings. It should be mentioned that the abandoned buildings are those in the category of buildings classified as having high seismic risk.

The measures proposed by the respondents regarding the development of infrastructure were mostly related to the extension of cultural infrastructure (museums and the arrangement of a summer theatre); facilities granted by the municipality for opening 
workshops and production spaces for creative industries; redevelopment of the underground passage that ensures access from the I.C. Brătianu Boulevard to the historical center (the entrance from Lipscani Street); and some proposals aiming to transform it into an unconventional art space. The importance of developing creative industries in the historical center of Bucharest was highlighted by $16 \%$ of the respondents as their main suggestion.

The proposals for improving services in the view of the respondents can be grouped into three directions: catering services (a larger share of traditional Romanian menus-this proposal is related to the fact that, in the historical center, there are several restaurants with international appeal, meeting the diversified requirements of foreign tourists); the improvement of cultural services (services that are better adapted to culturally motivated tourists, the diversification of cultural services, a higher degree of promotion of cultural activities, for example, festivals, especially in the online environment, the endowment of hotels with leaflets promoting cultural activities, and other ways of promoting cultural objectives, especially museums, e.g., festivals and the organization of open-air concerts); and the improvement of sanitation services (e.g., the presence of too few litter bins).

\section{Discussion}

\subsection{Significance of Findings}

This study focuses on applying the travel cost method to estimate the volume of tourist demand in the historical center of Bucharest and identify priorities related to the management of cultural heritage elements following tourists' proposals.

Regarding the application of the zonal travel cost method, as mentioned above, an improved calculation method has been developed; its efficiency is related to the fact that it takes into account both the physical distance and the travel time. This improved variant of the method reflects a series of spatial differences depending on the spatial distribution and quality of the national road network, which influences the degree of accessibility of the analyzed cultural destination for tourists. At the same time, it highlights interesting results, such as the average speed, which can be an important factor in business tourism and can cause a tourist destination to be visited more frequently [34]. Thus, certain areas crossed by highway segments can generate a greater flow of tourists, especially in the category of those who practice business tourism.

Assessing the frequency of visits to the analyzed historical site, using GIS in conjunction with the zonal transport cost method is an original approach because it yields better results by merging spatial analysis with the economic evaluation of cultural heritage. Several variables were taken into account (distance, morphological characteristics of terrain, distribution of road network, etc.) and the viability of joining the two methods was tested to better explain the variation in the number of tourists who visited the historical center of Bucharest. Thus, the results indicate how the degrees of accessibility influence the number of tourists. These results are relevant because they reflect the importance of accessibility for tourism. These results can be a useful element for spatial-planning decisions and decisions on developing the transport infrastructure.

In the case of single studies focusing on site evaluation using the individual travel cost method, it is particularly important to identify the relevant group of respondents. As previously highlighted, the first relevant group is the one represented by the respondents whose main motivation for tourism is to visit historical monuments $(67 \%$ of the total number of respondents). It is notable that one-third of the respondents practice business tourism or participate in congresses, having visiting cultural sites as a secondary motivation. This situation bears similarities to the results obtained in studies focusing on the analysis of the motivations of tourists who select Bucharest as a tourist destination, both for its cultural, historical, and artistic heritage and as a business destination (including conferences and exhibitions) [47]. Bucharest is among the most important destinations for corporate/business meetings, incentives, conferences, and exhibitions (MICE) at the national level, occupying the first place in terms of infrastructure [48]. At the same time, 
business tourism generates significant expenses, indicating that it represents an important and profitable market segment of the hospitality industry [49].

In the case of business tourism, tourists' proposals are largely related to the improvement of public catering services and the more intense promotion of cultural activities. This category of tourists is more interested in cultural activities, especially those held outdoors, due to the fact that they have the motivation to return to the analyzed cultural destination. Although the cultural motivation is secondary in their case, the wide range of cultural activities in which they can participate during the time that they allocate to recreation is extremely important.

The application of the travel cost method highlighted the strong correlation between the tourist attraction of the historical center of Bucharest and the willingness of tourists to pay to enjoy cultural objectives, which is reflected by the large tourist demand for this cultural destination, which attracts tourists from different regions. It is important to mention that the number of visits is correlated with the tourists' income and travel costs, regardless of the cultural significance of the historical center of Bucharest, a situation that is explained by the demand theory, according to which the number of visitors decreases with increasing travel costs and distance. Half of the respondents whose main motivation is to visit the cultural sites in the historical center of Bucharest will not return if the price of the trip increases by $20 \%$.

As previously mentioned, the travel cost method is useful because it provides information related to the perception of the state of conservation of heritage buildings and the opinions of tourists on the management priorities of these sites. Almost half of the respondents mentioned the action of conservation and the consolidation of some patrimonial assets from the historical center of Bucharest as being necessary. These tourists' recommendations are related to the fact that there are several heritage buildings facing seismic risk in the study area [50,51], some of which are in a precarious state of conservation.

Tourists who opt to engage in cultural tourism are concerned with preserving historical monuments or expanding the cultural infrastructure. An interest in the conservation of heritage buildings and suggestions for their cultural reuse (museums and creative industries) are noticeable among the tourists who participate in congresses.

Buildings with a low degree of conservation in the study area do not constitute a very large share, but they reflect the national situation related to the low funds allocated to culture and implicitly to the conservation of historical buildings. We must also mention the dynamics of aggressive factors, such as the rapid development of services, which have sometimes led to the loss of cultural heritage or the improper reuse of historical monuments. Particularly in the historical center of Bucharest, the renovation of heritage buildings has largely been determined by economic factors, with commercial, cultural, and tourist reuses. Most historical buildings in the center of the capital are reused for commerce, restaurants, and accommodation units, and, to a lesser extent, for cultural purposes [6]. As a rule, commercial reuses involve the renovation of rented commercial space on the first and, at most, the second level. The upper part of the building is not renovated, creating an unaesthetic image of these buildings despite their architectural value (Figure 4a,b).

However, it is also possible to highlight some positive examples, in which buildings that host restaurants have been completely renovated. In addition, some heritage buildings in the historical center of Bucharest have been preserved and renovated within cultural projects (the former Gabroveni inn has been transformed, after rigorous conservation action, into a cultural center) [6].

It is important to prioritize the consolidation of buildings to preserve historical monuments in the study area. In the last four years, several buildings that had been facing seismic risk in the historical center have been consolidated with funds allocated from the budget of the City Hall of Bucharest (Figure 5a,b). Visitors' perceptions should complement the expertise needed to conserve historical urban areas [52].

To maximize the recreational utility, it is important that the measures suggested by the respondents, with a dominant preference for cultural motivation and for knowledge, 
involve actions for the conservation of heritage buildings that are in a state of advanced degradation. The renovation of these buildings will contribute to their adaptive reuse in line with the needs of tourists but also of the local population. These measures can contribute to a high value of use of heritage buildings. Thus, the renovation and reuse of heritage buildings can generate visits to historical sites, at least in the case of the tourists who would not be constrained by an increase in the cost.

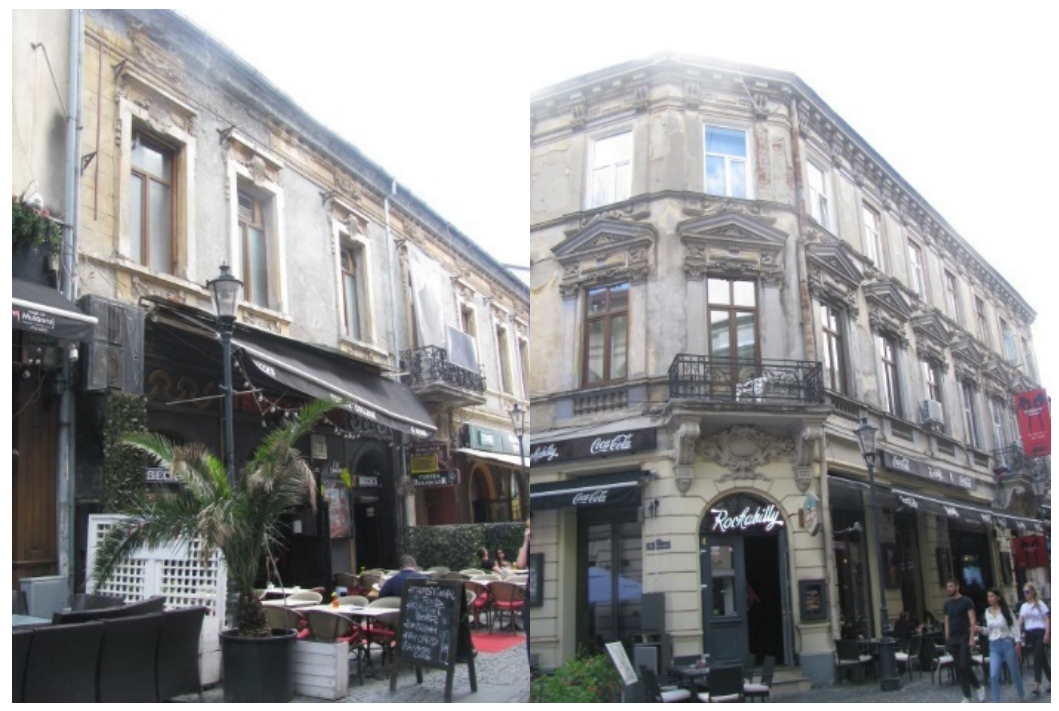

(a)

(b)

Figure 4. Historical buildings reused as restaurants in the historical center of Bucharest (a) Lipscani Street, (b) Covaci Street. Source: Merciu, G.L. (June 2019).

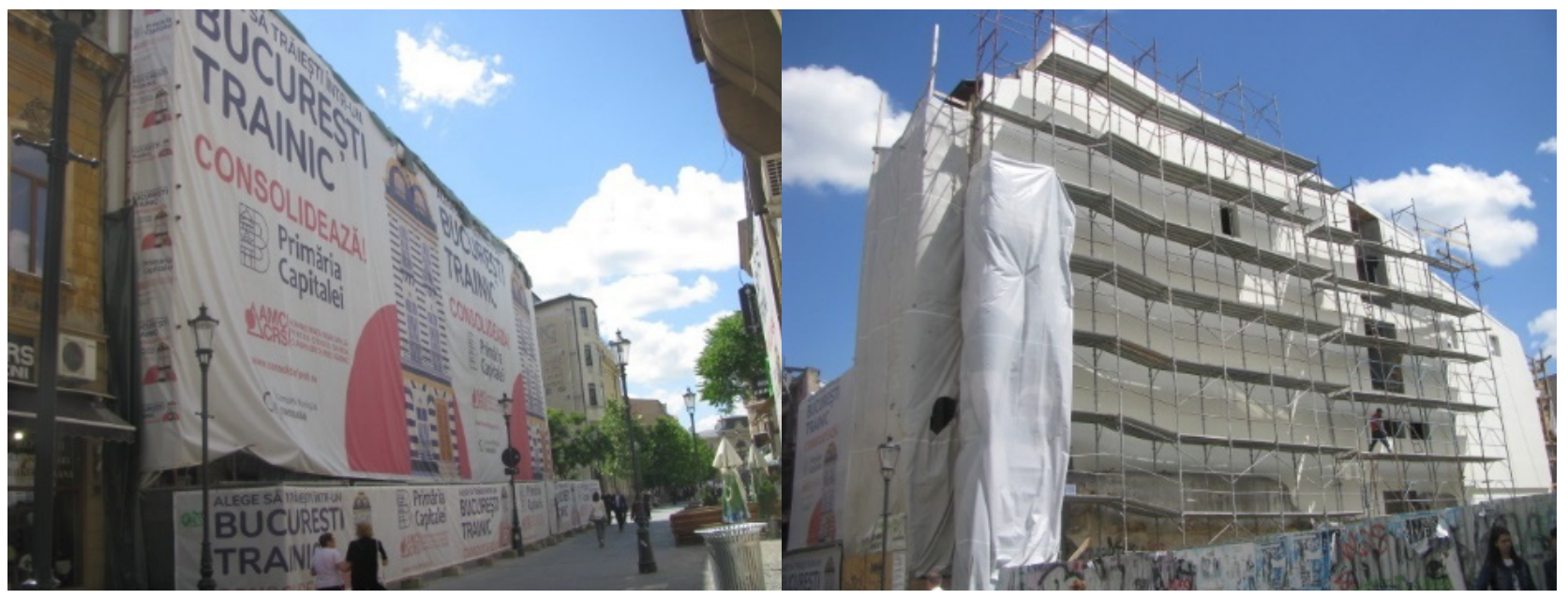

(a)

(b)

Figure 5. Historical buildings being consolidated in the historical center of Bucharest (a) Franceză Street (b) Lipscani Street. Source: Merciu, F.-C. (July 2019).

Cities have the capacity to stimulate the development of projects aimed at redesigning the physical structure through creative reuses of historical buildings and infrastructure elements [53]: the revitalization of the city center and property values and the reuse of heritage resources, adapting them to meet the present needs $[5,6,12,54]$. These transformations of urban space are the result of global neoliberalization and are planned as alternative measures of urban development [54-57]. Functional conversion projects occur with higher 
frequency in the historical area of cities in the process of urban regeneration due to the presence of a significant number of unused buildings, which are in different states of conservation $[5,53,58]$, but also as a result of the cultural attraction of the historical area exerted on tourists [53]. Urban historical centers are cultural tourist destinations due to the presence of civil and religious architectural monuments, museums, street structure [5,59-62], and "third spaces" (cafés, libraries) [53,60], as well as traditional retail markets [63] or quality of services [64].

Regarding the reuse of heritage buildings in the historical center of Bucharest, some respondents pointed out their potential to host creative industries. This proposal for reusing heritage buildings reflects both the higher educational training of the respondents and their knowledge of the importance of the urban regeneration process.

\subsection{Comparison with Other Studies}

The reliability of the travel cost method consists of the manner of modeling individual decision-making behavior regarding the selection of tourist destinations and the types of expenses incurred. Furthermore, to estimate the volume of the tourist demand in the historical center of Bucharest, the zonal transport cost method was used, which was improved by taking into account the accessibility criterion.

As mentioned previously, this study adopted the travel cost analysis method for assessing the economic value of buildings in the historical center of Bucharest for the first time. Other studies applying the same method use as case studies different cultural sites in Armenia [19], various cultural sites and a festival in Spain [20], an archaeological site in Taiwan [37], a cultural site in Jordan [14], a museum of national importance (Spain) [34], a historic city in the USA [33], cultural goods (blockbuster exhibition) [41], an old residence in Nigeria [38], cultural institutions in Sweden [35], etc.

An improvement of the zonal transport cost method was applied by taking into account a number of factors that can influence the degree of accessibility of a tourist destination. Thus, the present paper and other studies [45] highlight the different degrees of accessibility that can influence the dynamics of the tourist demand.

In most similar studies, the individual travel cost method is used, based on the application of a questionnaire in which the use values of cultural objects are evaluated as well as the behavior and expenses of tourists $[18,19,37,38]$. In the case of some studies, the structure of the questionnaire includes questions on the measures proposed by visitors to improve the quality of the tourist experience, with a focus on three categories: the conservation of heritage buildings, the improvement of infrastructure, and the improvement of services $[19,20,37]$.

In the present study, the travel costs were differentiated, taking into account the means of transport used by visitors, which also influenced the final cost, as in previous studies $[19,20,38]$. The interpretation of the results, using different statistical models, highlighted a number of similarities to previous studies. The predictors with the highest values were tourists' motivations; the quality of the recreational experience, which was strongly influenced by the specific characteristics of historical sites and the quality of the infrastructure; the desire to revisit a historic site, which was strongly influenced by the total cost of travel; and the income of visitors $[18-20,33,34,38]$. To these can be added other factors, such as tourists' education and age [11,17-20,33,36-38,41]. Some factors that stimulate visits are identified only in some studies, for example marital status $[18,19]$ and ethnic group [33]. In other studies, statistical modeling shows that some factors, such as age, income, and education, do not greatly influence the function of the demand [34]. Income is considered to be an important factor that influences the volume of tourist demand and is used in the evaluation models of historical sites, although it does not seem to have any significant effect on the evaluation of certain heritage sites [17].

In addition, the results of this study, as well as those of other previous studies, reflect one of the basic principles of the travel cost method according to which the greater the 
distance from the area of residence to the cultural destination, the lower the number of visits and the higher the costs of travel $[20,38]$.

\subsection{Importance of the Research}

The importance of this study results from the fact that it brings additional useful information into the complex analysis of the visiting models of domestic tourists as well as their behavior and expenses. The usefulness of this method also consists of the fact that it provides information related to tourists' perception of the degree of conservation of cultural heritage elements. This information can be used to establish priorities for the conservation and capitalization of cultural heritage buildings in the historical center of the capital city of Romania.

The application of the travel cost method facilitated the identification of the number of trips made and those expected in the hypothetical conditions that were used by the authors to deduce the value of use and importance given by tourists to the preservation of historical monuments.

As far as we know, this is the first study to have applied the travel cost method to analyze the number of visits of domestic tourists to the historical center of Bucharest. The economic value of heritage buildings in the studied area is analyzed in a previous study aimed at evaluating the nonuse values of historical buildings (employing the contingent valuation method) as well as the use values in terms of real estate values (measured by rental values) [6].

\subsection{Limitations and Future Research Directions}

The limitations of the study are related to the application of the method; one of the main criticisms of the model is its lack of accuracy in terms of information on the cost of travel. Although the respondents answered questions about the costs allocated to transportation, catering, and accommodation, it was difficult to calculate part of the specific cost, although various types of expenses provided in previous studies were taken into account.

It is important to note that another limitation of the study is that the assessment undertaken by applying the travel cost method is limited to the value of direct use of historical sites and is unable to assess their artistic or historical value, even if visitors selected the historical center of Bucharest for its historical, architectural, and cultural values.

Finally, it can be appreciated that subjectivity was a factor in choosing the case study, which could have influenced the results due to the fact that the capital city, the most important economic, cultural, and tourist center at the national level, was analyzed. In addition, this study was conducted on a single cultural site. The existence of alternative historical sites at the national level could naturally influence the tourist demand because the visit rate to historical sites depends not only on the cost of travel but also on the historical, architectural, and artistic values that can offer visitors the same level of utility.

Although the revealed preference methods have certain limitations, their application allowed for the assessment of the use values of heritage buildings in the historical center of the capital city, which may be useful in decision-making on their conservation and optimal use to be implemented by representatives of the local and central public administrations.

Subsequent research will focus mainly on a more in-depth evaluation of tourists' proposals concerning, on the one hand, the conservation measures of heritage buildings in the historical center of Bucharest, especially since several buildings have been identified as being at an advanced stage of degradation, and, on the other hand, the improvement of the infrastructure and services that would be useful to remedy the existing situation and ensure more benefits for the visitors, but also for the local population. 


\section{Conclusions}

The analysis of the results of this study, as well as of those of previous studies focusing on the economic evaluation of cultural-historical resources using the travel cost method, reflects the fact that historical monuments have high values of use due to their multiple valences. Cultural goods, especially those that stand out due to exceptional values, have a lower substitution rate than natural sites. In addition, the quality of cultural sites, reflected in the degree of conservation and the types of arrangements created for visits, can considerably influence the volume of tourists visiting a tourist destination. Tourists are less likely to opt for alternative cultural sites unless they have similar characteristics.

There are a number of limitations to this method regarding, on the one hand, the way in which the total cost of travel is established, especially in situations in which multiple recreational sites are analyzed, and, on the other hand, the evaluation of the use value of historical sites. The criticism is related to the fact that the travel cost method is based on a strictly economic approach and does not take into account specific values, such as historical or artistic values, which impose the difficulty of the economic evaluation of heritage assets.

However, by applying this method, a hierarchy of historical monuments can be established according to the preferences of tourists, and the significance of this information depends ultimately on both the acceptance of the premises of the model and the subsequent use of its results. Starting from these premises, it is confirmed in numerous studies that the choice of a person to visit a historical site is determined by the experience and quality of that site, so it can be concluded that well-preserved and well-arranged historical sites are selected by tourists based on their specific characteristics and that this method indirectly reflects the hierarchy of heritage buildings. In relation to this idea, previous studies highlight that the value guides tourists in their decision-making, including selecting activities that meet the tourists' knowledge and recreation motivations, which are frequently associated with visiting cultural sites. At the same time, this method is useful because it is based on the simple and reasonable assumption that travel costs reflect the use value of recreational sites, as opposed to the contingent method, which is based on strictly hypothetical situations.

Author Contributions: Conceptualization, F.-C.M.; methodology, F.-C.M., A.-I.P. and G.-L.M.; software, G.-L.M. and A.-I.P.; validation, F.-C.M., A.-I.P. and G.-L.M.; formal analysis, F.-C.M. and A.-I.P.; investigation, F.-C.M.; resources, F.-C.M.; data curation, F.-C.M., A.-I.P. and G.-L.M.; writing-original draft preparation, F.-C.M.; writing-review and editing, F.-C.M. and A.-I.P.; visualization, F.-C.M., A.-I.P. and G.-L.M.; supervision, F.-C.M.; project administration, F.-C.M.; funding acquisition, F.-C.M. All authors have read and agreed to the published version of the manuscript.

Funding: This work was supported by a grant of the Romanian Ministry of Research and Innovation CCCDI-UEFISCDI, project number 52PCCDI/2018 PN-III-P1-1.2-PCCDI-2017-0686: “Complex multidisciplinary platform for integrative and systematic research of identities and tangible and non-tangible cultural heritage in Romania".

Institutional Review Board Statement: Not applicable.

Informed Consent Statement: Not applicable.

Data Availability Statement: Data was obtained within a project funded by the Romanian Ministry of Research and Innovation CCCDI-UEFISCDI and is available from the authors by request.

Acknowledgments: Not applicable.

Conflicts of Interest: The authors declare no conflict of interest.

\section{References}

1. Lee, W.; Chhabra, D. Heritage hotels and historic lodging: Perspectives on experiential marketing and sustainable culture. J. Herit. Tour. 2015, 10, 103-110. [CrossRef]

2. Chhabra, D. Optimizing authenticity: The dialectics heritage. Collect. A J. Mus. Arch. Prof. 2020, 16, 135-138.

3. Bottero, M.; D'Alpaos, C.; Marello, A. An application of the A'WOT analysis for the management of cultural assets: The case of historical farmshouses in the Aglié Castle (Turin). Sustainability 2020, 12, 1071. [CrossRef] 
4. Kharitonov, A.; Smirnova, O.; Vilenskii, M. Principal of green architecture for the historical part of Saint-Petersburg. Urban. Archit. Constr. 2019, 10, 103-112.

5. Merciu, F.-C.; Ianoș, I.; Cercleux, A.-L.; Merciu, G.-L. Evaluation of the economic values of urban heritage in the central area of Ploiesti municipality. In Proceedings of the International Conference Knowledge-Based Organization, Sibiu, Romania, 11-13 June 2020; De Gruyter: Warsaw, Poland, 2020; Volume 26, pp. 58-62.

6. Merciu, F.-C.; Cercleux, A.-L.; Merciu, G.-L.; Secăreanu, G. Evaluation of the economic values of heritage buildings in the historical center of Bucharest Municipality. In Organisations and Performance in a Complex World, Proceedings of 25th International Economic Conference of Sibiu (IECS 2019), Sibiu, Romania, 24-25 May 2019; Orăstean, R., Ogrean, C., Mărginean, S.V., Eds.; Springer Proceedings in Business and Economics: Cham, Switzerland, 2021; pp. 159-175.

7. Messaoudi, S.; Messaci, N.; Chennaoui, Y. Classifying heritage resources of territories. Case of Bejaia. Urban. Archit. Constr. 2021, 12, 107-132.

8. Nae, M.; Dumitrache, L.; Suditu, B.; Matei, E. Housing activism initiatives and land-use conflicts: Pathways for participatory planning and urban sustainable development in Bucharest city, Romania. Sustainability 2019, 11, 6211. [CrossRef]

9. Navrud, S. Valuing cultural heritage-Lessons learned. Struct. Stud. Repairs Mantenance Herit. Archit. 2005, 9, 95-100. [CrossRef]

10. Lequeux-Dinca, A.I.; Preda, M.; Taloş, A.M. Empirical evidences on foreign tourist demand perception of Bucharest. Almatourism 2018, 17, 95-116. [CrossRef]

11. Yung, E.H.K.; Yu, P.L.H.; Chan, E.H.W. Economic valuation of historic properties: Review and recent developments. Prop. Manag. 2013, 31, 335-358. [CrossRef]

12. Throsby, D. Cultural capital and sustainable concepts in the economics of cultural heritage. In Assessing the Values of Cultural Heritage Research Report; de la Marta, T., Ed.; The Getty Conservation Institute: Los Angeles, CA, USA, $2002 ;$ pp. $101-117$.

13. Li, Y.; Zhao, L.; Huang, J.; Law, A. Research frameworks, methodologies, and assessment methods concerning the adaptive reuse of architectural heritage: A review. Built Heritage 2021, 5, 1-19. [CrossRef]

14. Elsorady, D.A. Assessment of the compatibility of new uses for the heritage buildings: The example of Alexandria National Museum, Alexandria, Egypt. J. Cult. Herit. 2014, 15, 511-521. [CrossRef]

15. Amato, A.; Andreoli, M.; Rovai, M. Adaptive reuse of a historic building by introducing new functions: A scenario evaluation based on participatory MCA applied to a former Carthusian Monastery in Tuscany, Italy. Sustainability 2021, 13, 2335. [CrossRef]

16. Bottero, M.; D'Alpaos, C.; Oppio, A. Ranking of adaptive reuse strategies for abandoned industrial heritage in vulnerable contexts: A multiple criteria decision aiding approach. Sustainability 2019, 11, 785. [CrossRef]

17. Wright, W.C.C.; Eppink, F.V. Drivers of heritage value: A meta-analysis of monetary valuation studies of cultural heritage. Ecol. Econ. 2016, 130, 277-284. [CrossRef]

18. Abuamoud, I.N.; Libbin, J.; Green, J.; Rousan, R.A.L. Factors affecting the willingness of tourists to visit cultural heritage sites in Jordan. J. Her. Tour. 2014, 9, 148-165. [CrossRef]

19. Alberini, A.; Longo, A. The value of cultural heritage sites in Armenia: Evidence from a travel cost method study. In Sustainability Indicators and Environmental Valuation Working Papers 12223; Fondazione Eni Enrico Mattei (FEEM): Milan, Italy, 2005; pp. 1-40. [CrossRef]

20. Bedate, A.; Herrero, L.C.; Sanz, J.A. Economic evaluation of the cultural heritage: Application to four case studies in Spain. J. Cult. Herit. 2004, 5, 101-111. [CrossRef]

21. Iorgulescu, F.; Alexandru, F.; Crețan, G.C.; Kagitci, M.; Iacob, M. Consideration regarding the valuation and valorization of cultural heritage. Theor. Appl. Econ. 2011, 28, 15-32.

22. Misirlisoy, D.; Günçe, K. Assessment of the adaptive reuse of castle as museums: Case of Cyprus. Int. J. Sustain. Dev. Plan. 2016, 11, 147-159. [CrossRef]

23. Ilja, A.; Broström, T. The sustainable viability of adaptive reuse of historic buildings: The experiences of two World Heritage old cities; Bethlehem in Palestine and Visby in Sweden. Int. Invent. J. Arts Soc. Sci. 2015, 2, 52-66.

24. Ost, C. Mapping heritage economics for the spatial analysis in historic city cores. In The Economic of Uniqueness. Investing in the Historic City Cores and Cultural Heritage Assets for Sustainable Development; Licciardi, G., Amirtahmasebi, R., Eds.; The World Bank: Washington, DC, USA, 2012; pp. 245-284.

25. Mainardi, P. Postmodern history at the Musée d'Orsay. JSTOR 1987, 41, 30-52. [CrossRef]

26. Bullen, P.A.; Love, P.E.D. Adaptive reuse of heritage buildings. Struct. Surv. 2011, 29, 411-421. [CrossRef]

27. Mason, R. Assessing values in conservation planning: Methodological issues and choices. In Assessing the Values of Cultural Heritage Research Report; de la Marta, T., Ed.; The Getty Conservation Institute: Los Angeles, CA, USA, $2002 ;$ pp. 5-30.

28. Karoglou, M.; Kyvelou, S.S.; Boukouvalas, C.; Theofani, C.; Bakolas, A.; Krokida, M.; Moropoulou, A. Towards a preservationsustainability nexus: Applying LCA to reduce the environmental footprint of modern built heritage. Sustainability 2019, $11,6147$. [CrossRef]

29. Agapiou, A.; Lysandrou, V.; Hadjimitsis, D.G. The Cyprus coastal heritage landscapes within marine spatial planning process. J. Cult. Herit. 2017, 23, 28-36. [CrossRef]

30. Tu, H.-M. The attractiveness of adaptive heritage reuse: A theoretical framework. Sustainability 2020, 12, 2372. [CrossRef]

31. Fonseca, S.; Rebelo, J. Economic valutation of cultural heritage: Application to a museum located in the Alto Douro wine region-World heritage site. PASOS Rev. Tur. Y Patrim. Cult. 2010, 8, 339-350. [CrossRef] 
32. Çay, R.; Taşl1, T.C. Determination of recreational and tourism use value of Boycaada by travel cost analysis methods. Pol. J. Environ. Stud. 2021, 30, 35-45. [CrossRef]

33. Poor, P.J.; Smith, J.M. Travel cost analysis of a cultural heritage site: The case of historic St. Mary's city of Maryland. J. Cult. Econ. 2004, 28, 217-229. [CrossRef]

34. Torres-Ortega, S.; Pérez-Álvarez, R.; Díaz-Simal, P.; de Luis-Ruiz, J.M.; Piña-García, F. Economic valuation of cultural heritage: Application of travel cost method to the National Museum and research center of Altamira. Sustainability 2018, 10, 2550. [CrossRef]

35. Armbrecht, J. Use value of cultural experiences: A comparison of contingent valuation and travel cost. Tour. Manag. 2014, 42, 141-148. [CrossRef]

36. Leh, F.C.; Mokhtar, F.Z.; Rameli, N.; Ismail, K. Measuring recreational value using travel cost method (TCM): A number of issues and limitations. Int. J. Acad. Res. Bus. Soc. Sci. 2018, 8, 1381-1396. [CrossRef]

37. Chen, C.-C.; Lee, C.-H. Economic benefits of improving the quality of cultural heritage sites. J. Econ. Manag. 2017, 13, 241-264.

38. Egbenta, I.R. Application of travel cost method to valuation of historic building: Old residence in Calabar, Nigeria. Middle-East J. Sci. Res. 2017, 25, 1925-1933. [CrossRef]

39. Špaček, J.; Antoušková, M. Individual single-site travel cost model for Czeck Paradise Geopark. Acta Univ. Agric. Silvic. Mendel. Brun. 2013, 61, 2851-2858. [CrossRef]

40. Cesario, F.J.; Knetsch, J.L. Time bias in recreation benefit estimates. Water Resour. Res. 1970, 6, 700-704. [CrossRef]

41. Vicente, E.; de Frutos, P. Application of the travel cost method to estimate the economic value of cultural goods: Blockbuster art exhibitions. Rev. Econ. Publica 2011, 196, 37-63.

42. Common, M.; Bull, T.; Stoeckl, N. The Travel cost method: An empirical investigation of Randall's difficulty. Aust. J. Agric. Resour. Econ. 1999, 43, 457-477. [CrossRef]

43. Sandu-Cuculea, V. Archaeological research on the territory of the Royal Old Court in Bucharest Curtea Veche Voivodeship Palace. The square at the intersection of Şelari and Iuliu Maniu streets. St. Anton Square. Archaeol. Res. Buchar. 2009, 8, 122-196.

44. Clawson, M.; Knetsch, J. Economics of outdoor recreation; John Hopkins University Press: Baltimore, MD, USA, 1966; pp. 156-159.

45. Bulai, M.; Ursu, A. Creating, testing and applying a GIS road travel cost model for Romania. Geogr. Tech. 2012, 1, 8-18.

46. Dumitrache, L.; Nae, M.; Simion, G.; Taloş, A.-M. Modelling potential geographical access of the population to public hospitals and quality health care in Romania. Int. J. Environ. Res. Public Health 2020, 17, 8487. [CrossRef]

47. Popescu, R.I.; Profiroiu, A.G. Comparative study regarding EU urban areas tourism promotion using official websites-Examples of good practices for Romania' s capital city. Transylvania Rev. Adm. Sci. 2012, 35E, 219-237.

48. Mureşan, M.L.; Nistoreanu, P. MICE—The valorization of local communities' resources. Case study-Romania. In Proceedings of the Management International Conference, Venice, Italy, 24-27 May 2017; pp. 417-429.

49. Anagnostou, A.; Ekonomou, G.; Kallioras, D. The nexus of tourism spending with economic performance: A panel data analysis for the Eurozone area. Geogr. Pannonica 2021, 25, 53-62. [CrossRef]

50. Boştenaru Dan, M.; Armas, I. Earthquake impact on settlements: The role of urban and structural morphology. Nat. Hazards Earth Syst. Sci. 2015, 15, 2283-2297. [CrossRef]

51. Merciu, C.; Ianos, I.; Merciu, G.-L.; Jones, R.; Pomeroy, G. Mapping accessibility for earthquake response in the historic urban centre of Bucharest. Nat. Hazards Earth Syst. Sci. 2018, 18, 2011-2026. [CrossRef]

52. Najd, M.D.; Ismail, N.A.; Maulan, S.; Yunos, M.Y.M.; Niya, M.D. Visual preference dimensions of historic urban areas: The determinants for urban heritage conservation. Habitat Int. 2015, 49, 115-125. [CrossRef]

53. Usai, A. How creative professionals reshape the historic city. The perspective of architects as managers of coworking spaces in Villanova district, Cagliary city. Territ. Identity Dev. 2019, 4, 35-50. [CrossRef]

54. Walker, M. Cities as creative spaces for cultural tourism: A plea for the consideration of history. PASOS Revista de Turismo y Patrimonio Cultural 2010, 8, 17-26. [CrossRef]

55. Oliveira, R.A.; Lopes, J.; Sousa, H.; Abreu, M.I. A system for the management of old building retrofit projects in historical centres: The case of Portugal. Int. J. Strat. Prop. Manag. 2017, 21, 199-211. [CrossRef]

56. Teodorescu, C.; Vanturache, R.; Teodorescu, O.; Diaconu, D.C. Proposal for functional conversions-Bucharest Faur. Urban. Archit. Constr. 2016, 7, 137-146.

57. Vesalon, L.; Crețan, R. "Little Viena” or European avant-garde city? Branding narratives in a Romanian city. J. Urban Reg. Anal. 2019, 9, 19-34. [CrossRef]

58. Rădulescu, V.M.; Rădulescu, G.M.T.; Naş, S.; Rădulescu, A.T.; Bondrea, M.; Rădulescu, C.M. Synthetic analysis of geoinformatics technologies for preservation of cultural heritage, methodological approach. J. Appl. Eng. Sci. 2021, 11, 33-40. [CrossRef]

59. Kyvelou, S.; Bobolos, N.; Tsaligopoulos, A. Exploring the effects of "smart city" in the inner-city fabric of the Mediterranean metropolis: Towards a bio-cultural sonic diversity? Heritage 2021, 4, 39. [CrossRef]

60. Dumitrache, L.; Nae, M. Urban regeneration and affective connections to place in Bucharest ciy centre. Ann. Univ. Buchar. Geogr. Ser. 2013, 64, 187-202.

61. Şeker, B.S.; Büyükgüner, G. Assessment of the performance of the Amasya Bayezid II Mosque under static and dynamic loads. J. Appl. Eng. Sci. 2021, 11, 53-60. [CrossRef]

62. Taloş, A.M.; Lequeux-Dincă, A.-I.; Preda, M.; Surugiu, C.; Vijulie, I. Silver tourism and recreational activities as possible factors to support active ageing and the resilience of the tourism sector. J. Settl. Spat. Plan. 2021, 8, 29-48. [CrossRef] 
63. Guimarães, P. The evolution of old shopping centres in the town centre of Braga, Portugal. J. Urban Reg. Anal. 2018, 10, 127-141. [CrossRef]

64. Castillo Canalejo, A.M.; Jimber del Río, J.A. Quality, satisfaction and loyalty indices. J. Place Manag. Dev. 2018, 11, 426-446. [CrossRef] 